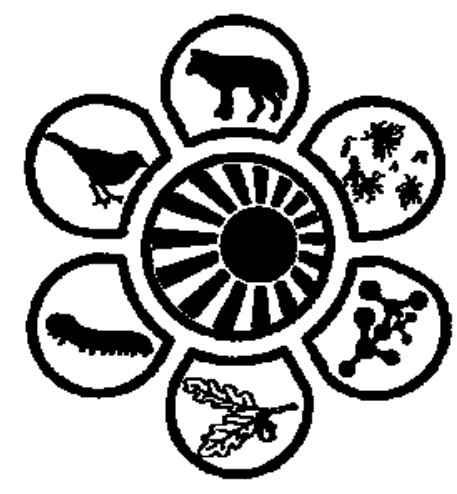

Вісник Дніпропетровського університету. Біологія, екологія.

Vìsnik Dnìpropetrovs'kogo unìversitetu. Seriâ Bìologiâ, ekologiâ

Visnyk of Dnipropetrovsk University. Biology, ecology.

Vìsn. Dnìpropetr. Unìv. Ser. Bìol. Ekol. 2015. 23(2), 154-160.

doi: $10.15421 / 011522$

ISSN 2310-0842 print

ISSN 2312-301X online

www.ecology.dp.ua

УДК 594.381.5:574.64

\title{
Вплив концентрації амоній хлориду на вміст каротиноїдних пігментів в організмі Lymnaea stagnalis
}

\author{
Г.С. Киричук, Л.В. Музика
}

Житомирський державний університет імені Івана Франка, Житомир, Украӥна

Вивчено вплив різних концентрацій амоній хлориду (0,5, 2, 5 та 10 ГДК) на вміст $\beta$-каротину та ксантофілів у гемолімфі, гепатопанкреасі, мантії та нозі Lymnaea stagnalis (Linnaeus, 1758) (Pulmonata, Lymnaeidae). Досліджено вміст у тканинах (органах) молюсків обговорюваних каротиноїдів за різної експозиції $(2,7,14$ та 21 доба) перебування тварин у токсичному середовищі. Зміни показників мають дозозалежний характер, значно варіюють залежно від тривалості інтоксикації та характеризуються тканинноорганною специфічністю. Допорогові концентрації $\mathrm{NH}_{4} \mathrm{Cl}(0,5$ ГДК) за короткострокової експозиції (2 доби) викликають збільшення вмісту $\beta$-каротину (в 1,63-1,81 раза) та ксантофілів (в 1,71-1,89 раза) у всіх досліджених органах молюсків. За дії токсиканта, концентрація якого відповідала 2 ГДК, відмічено підвищення вмісту $\beta$-каротину в усіх тканинах і органах, а ксантофілів - лише у гемолімфі L. stagnalis. За умов пролонгування інтоксикації до 7 діб посилюється інгібувальний вплив амоній хлориду на метаболізм досліджуваних тварин, що проявляється зменшенням вмісту $\beta$-каротину в усьому їх тілі на 23,6-96,0\% незалежно від концентрації полютанта. Збільшення концентрації токсиканта до 5-10 ГДК незалежно від тривалості експозиції викликає зниження вмісту $\beta$-каротину у гемолімфі (на 39,9-92,6\%) та гепатопанкреасі (на 11,2-95,7\%) тварин. За експозиції 21 доба у розчинах з амоній хлоридом (0,5 ГДК) зростає вміст $\beta$-каротину у тканинах та органах молюсків, а в міру збільшення токсичності середовища (2-10 ГДК) зафіксовано зменшення вмісту каротиноїдних пігментів в усіх досліджених тканинах та органах L. stagnalis: $\beta$-каротину на 52,1-93,5\%, ксантофілів на 29,9-91,6\%.

Ключові слова: $\beta$-каротин; ксантофіли; антиоксидантна активність; окиснювальний стрес; метаболічна адаптація; прісноводні молюски

\section{The effect of ammonium chloride concentrations on the content of carotenoid pigments in the body of Lymnaea stagnalis}

\author{
G.E. Kyrychuk, L.V. Muzyka \\ Zhytomyr Ivan Franko State University, Zhytomyr, Ukraine
}

The paper deals with the peculiarities of distribution of $\beta$-carotene and xanthophylls in the body of Lymnaea stagnalis (Linnaeus, 1758) (Pulmonata, Lymnaeidae) in the normal conditions and under the action of different concentrations of $\mathrm{NH}_{4} \mathrm{Cl}$, depending on duration of exposure $\left(2,7,14\right.$ and 21 days). L. stagnalis (300 copies) were collected in September 2013-2014 (in Zhytomyr region). Toxicant $\mathrm{NH}_{4} \mathrm{Cl}$ was used in concentrations corresponding to $0.5,2,5$ and $10 \mathrm{MAC}$. The content of $\beta$-carotene and xanthophylls was determined by the Taylor method. 2400 biochemical analyses were carried out. The article shows that under the action of $0.5 \mathrm{MPC} \mathrm{NH}_{4} \mathrm{Cl}$ adaptive processes are stimulated in the body of $L$. stagnalis and total antioxidant activity is activated, as evidenced by changes in the content of $\beta$-carotene and xanthophylls in the organs (hepatopancreas, pallium and foot) and tissues (hemolymph) of the mollusks under study. The research proves that the action of concentration discussed above during 2,14 and 21 days causes the increase in the content of $\beta$-carotene in hepatopancreas (1.63-5.73 times), pallium (1.68-5.37 times) and foot (1.81-3.89 times) of animals. Incubation of mollusks in solutions of $\mathrm{NH}_{4} \mathrm{Cl}$ (0.5 MAC) for 7 days resulted in the decrease of figures in these organs by $23,6-38,8 \%$ relatively to control. It should be noted that from the overall dynamics hemolymph is somewhat distracting; for it 1.35-1.46 times' decrease in the content of $\beta$-carotene after short-term action of the toxicant ( 2 and 7 days) and $\beta$-carotene increase by 2.79-7.38 times under conditions of prolonged exposure (14 and 21 days) is recorded. The content of xanthophylls correlates with the content of $\beta$-carotene on the $2^{\text {nd }}, 7^{\text {th }}$ and $14^{\text {th }}$ day of toxic action, but by increasing the time of contact with toxic substances to 21 days the decrease in figures by $20,9-40,7 \%$ in foot and pallium is recorded. When the toxicant

Житомирський державний університет імені Івана Франка, вул. Велика Бердичівська, 40, Житомир, 10008, Украӥна Zhytomyr Ivan Franko State University, V. Berdychivska Str., 40, Zhytomyr, 10008, Ukraine Tel.: +38-067-961-96-86, +38-097-648-90-81.E-mail: kyrychuk@zu.edu.ua, lidiya.muzyka@ukr.net 
concentration is increased to 2 MAC (with 2 days' exposition) $\beta$-carotene content grows 2,08-5.98 times throughout the body of $L$. stagnalis and xanthophyll content decreases in hepatopancreas, pallium and foot (by 51,8-67,3\%). When increasing duration of exposure in solutions of this concentration to 7,14 and 21 days the decrease is recorded in both parameters studied: $\beta$-carotene (by 52.1-73,8\% in hepatopancreas, by $31,7-69,0 \%$ in pallium, by $56,1-80,6 \%$ in foot) and xanthophylls (by $44,6-82,6 \%$ in hepatopancreas, by $51,6-68,2 \%$ in pallium, $75,6-$ $83,8 \%$ in foot). Increase in the toxicant concentration to 5 and 10 MAC regardless of the length of the exposure leads to reduction of the content of animals' $\beta$-carotene in hemolymph (by 39,9 - of 92.6\%) and hepatopancreas $(11,2-95,7 \%$ ). In the mollusk foot the decrease of figures under action of 5 and 10 MAC of the toxicant during 7, 14 and 21 days (by 33,2-94,8\% relative to control) irrespective of the exposure duration is recorded. Long stay (14 and 21 days) in solutions of the toxicant at the concentration of 5 and 10 MAC causes the reduction of xanthophyll content throughout the body of L. stagnalis. Tissue-specific distribution of $\beta$-carotene and xanthophylls in the tissues (organs) of L. stagnalis is shown. Hemolymph is characterized by minimum content of investigated pigments, and maximum values vary between organs (tissues) depending on the concentration and duration of exposure of animals to the toxic solution.

Keywords: $\beta$-carotene; xanthophylls; antioxidant activity; oxidative stress; metabolic adaptation; freshwater mollusks

\section{Вступ}

Окиснювальний стрес, що стимулюється надлишковими концентраціями ксенобіотиків у водному середовищі, зокрема, хлоридом амонію, який володіє сильно вираженими окиснювальними властивостями (Metelev et al., 1971), зумовлює індукцію вільнорадикальних процесів у клітинах гідробіонтів і посилення процесів перекисного окиснення ліпідів (ПОЛ). Утворення надлишкових кількостей перекисних продуктів спричинює порушення структурної та функціональної організації клітинних мембран, зміни їх проникності та іонного балансу у клітині, роз'єднання окиснювального фосфорилювання, окиснення тіольних груп білків, дезактивації ферментів, порушення структури ДНК, енергетичного метаболізму та інгібування синтезу АТФ (Parke, 1987; Gautam and Parihar, 1996; Leus, 1998). У клітинах живих організмів існують антиоксидантні системи захисту від вільних радикалів (Ercal et al., 2001), ефективність дії яких визначається не лише активністю спеціалізованих ферментів, а і неспецифічною ланкою, в якій одна із ключових ролей належить каротиноїдам (Johnson, 2002; Gostjuhina et al., 2012). Каротиноїдні пігменти здатні взаємодіяти 3 активними формами кисню або вільними радикалами, тим самим підтримуючи необхідний рівень окиснювальних процесів у тканинах, перешкоджаючи розвитку оксидантного стресу, викликаного токсикантом (Simahina, 2010; Gostjuhina et al., 2012). Крім цього, каротиноїди нейтралізують перекисні радикали та запобігають перекисному окисненню ліпідних компонентів клітинних мембран (Halliwell and Gutteridge, 1985). Вміст каротиноїдних пігментів прісноводних молюсків вивчено не повною мірою, а питання зміни концентрацій $\beta$-каротину та ксантофілів в організмі Lymnaea stagnalis (Linnaeus, 1758) (Pulmonata, Lymnaeidae) за умов інтоксикації амоній хлоридом за різної експозиції зовсім не вивчене, що і зумовило наші дослідження.

\section{Матеріал і методи досліджень}

Об’єкт дослідження - 300 екз. L. stagnalis, зібрані на о. Мельком (с. Сонячне Житомирського р-ну Житомирської обл.). Експериментальні дослідження проводили у вересні 2013-2014 рр. Контролем у всіх дослідах слугували молюски, яких утримували у дехлорованій (шляхом відстоювання протягом доби) водопровідній воді. Тварини, використані в токсикологічних дослідах, попередньо підлягали 14-добовій аклімації до умов лабораторного утримування (Hlebovich, 1981). Як токсикант використано $\mathrm{NH}_{4} \mathrm{Cl}$ у концентраціях, що відповідали 0,5 , 2, 5 та 10 ГДКрибогосп. (ГДКрибогосп. $\mathrm{NH}_{4}^{+}$дорівнює $0,5 \mathrm{мг} /$ дм $\left.^{3}\right)$. Тривалість токсикологічних експериментів $2,7,14$ та 21 доба. Із метою запобігання впливу на піддослідних L. stagnalis власних екзометаболітів, в акваріумах щодня змінювали воду на свіжу тієї ж якості. Вимірювання морфометричних параметрів проводили штангенциркулем. Тотальну масу тіла та масу органів (тканин) тварин установлювали на електронних вагах (WPS 1200) 3 точністю до 0,01 г. Для уникнення впливу на показники біотичного чинника для дослідження обрано лише неінвазованих особин. В експерименті використано гепатопанкреас, мантію та ногу, які отримували, анатомуючи тварин, а також гемолімфу, отриману методом прямого знекровлення (Stadnichenko, 1970). Для визначення вмісту $\beta$-каротину та ксантофілів зразки тканин і органів гомогенізували та проводили екстракцію гексаном (1:4). Сумарний вміст визначали за методикою (Tailor, 1976). Усього виконано 2400 біохімічних аналізів. Отримані експериментальні дані оброблено методами варіаційної статистики з використанням пакета прикладних програм Statistica 6.0. На діаграмах показано середні значення та стандартну похибку (std. error).

\section{Результати та їх обговорення}

Компенсаторно-адаптивна відповідь організму гідробіонтів на дію токсикантів визначається швидкістю та механізмом надходження полютанта до клітин, тканин і органів, ступенем його накопичення в метаболічноактивних структурах, а також їх фізико-хімічними властивостями та фізіологічною роллю в організмі (Grubinko, 2011). За своєю фізіологічною дією аміак та іони амонію виступають токсикантами комбінованої дії, здійснюють локальний, гемолітичний і нервово-паралітичний вплив на організм гідробіонтів, послаблюють їх адаптивні можливості, знижують життєстійкість та викликають порушення низки метаболічних процесів, які часто можуть мати летальний наслідок (Metelev et al., 1971).

Найхарактерніші симптоми стресу гідробіонтів за дії амонійних сполук - почастішання серцебиття, посилення інтенсивності дихання, зростання гепатосоматичного індексу. Крім цього, іони амонію можуть зумовлювати поступове зміщення абсорбційної конфігурації насиченого киснем гемоглобіну у бік деоксигенації, що викликає ацидемію та порушення здатності дихальних пігментів переносити кисень (Lappivaara, 2001; Tilak et al., 2002; Potrohov, 2008). Відомо (Britton, 1986), що в разі підвищеної метаболічної активності клітини, яка зумовлюється 
забрудненням навколишнього середовища, швидкість надходження кисню через клітинну мембрану не задовольняє зростаючих потреб дихального ланцюга, саме тому в організмі гідробіонтів зростає активність каротиноїдів, роль яких в окиснювальному метаболізмі клітини зумовлена великою кількістю спряжених подвійних зв'язків у молекулах i використанням частини цих зв'язків для утворення внутрішньоклітинного депо кисню (або запасів органічного акцептора електронів) у клітинах тварини, які перебувають в умовах гіпоксії.

Вміст $\beta$-каротину в організмі L. stagnalis 32 токсичної дії амоній хлориду. Низька концентрація амоній хлориду (0,5 ГДК) уже на кінець другої доби викликала стимуляцію обмінних процесів в організмі L. stagnalis та активацію його загальної антиоксидантної
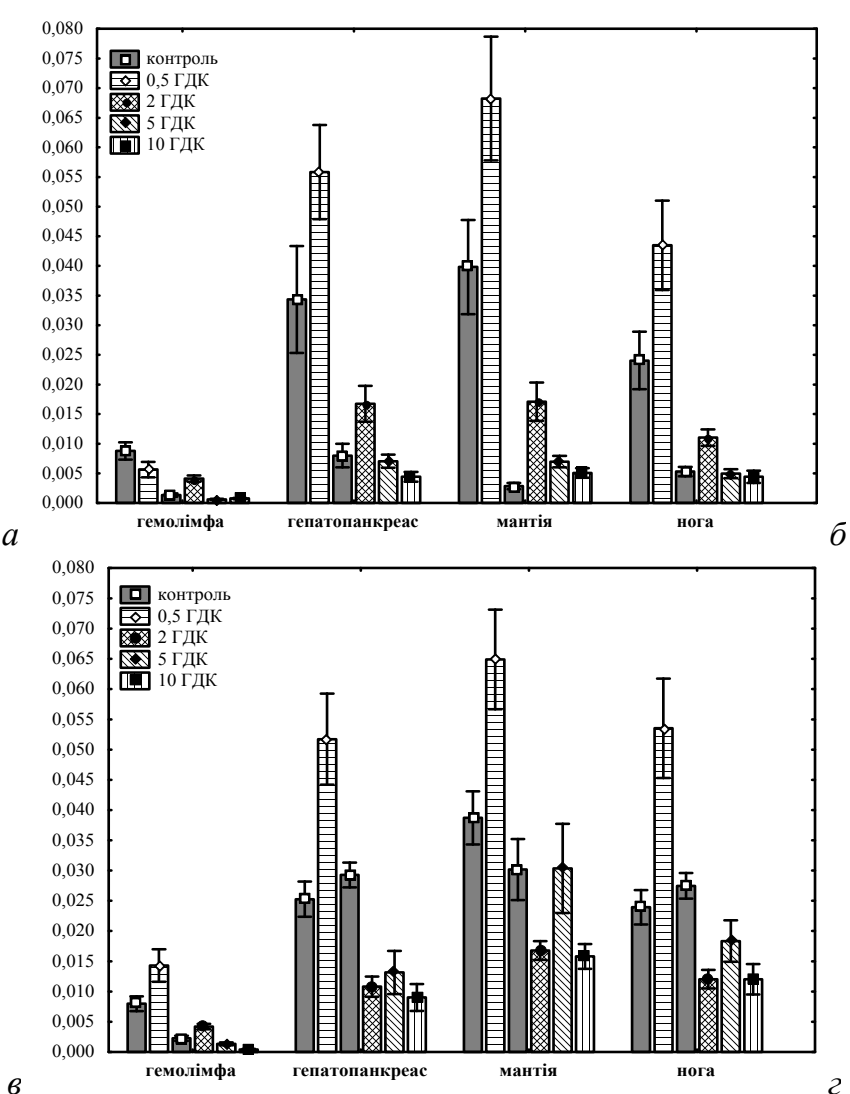

активності (яка має компенсаторний характер і виникає у відповідь на токсичну дію), що проявилася збільшенням вмісту $\beta$-каротину майже в усьому тілі досліджуваних тварин: на $62,7 \%$ у гепатопанкреасі, на $71,6 \%$ у мантії та на $81,3 \%$ у нозі $(\mathrm{P}<0,01)$. Для гемолімфи відмічене зниження обговорюваного показника на $35,2 \%$. Збільшення вмісту $\beta$-каротину в усьому організмі L. stagnalis (у 2,09-5,97 раза) корелює зі збільшенням у воді дози токсиканта до концентрації, яка відповідала 2 ГДК, що $є$ результатом підвищення неспецифічної резистентності організму молюсків за інтоксикації, та, імовірно, вказує на адаптаційну фазу стресу, пов'язану 3 мобілізацією енергетичних ресурсів, необхідних для життєзабезпечення та виживання тварин у токсичному середовищі (рис. 1).
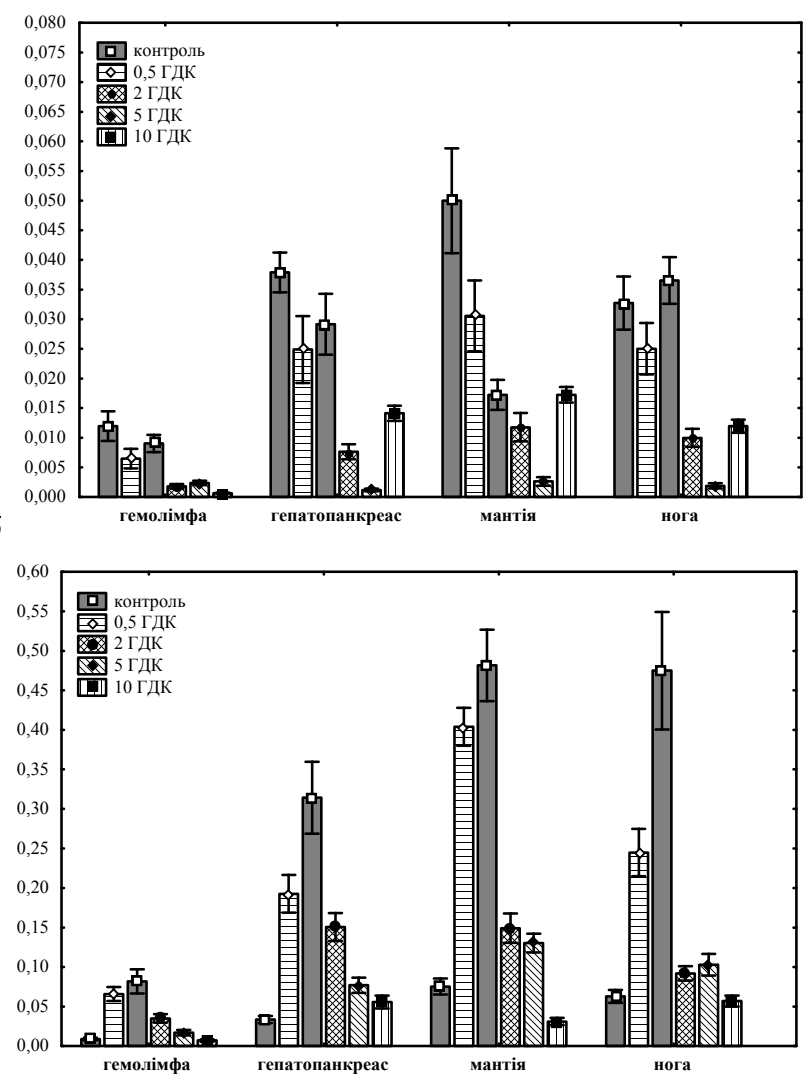

Рис. 1. Вплив амоній хлориду (0,5-10 ГДК) на вміст ß-каротину в організмі L. stagnalis:

$a$ - експозиція 2 доби, $\sigma-7$ діб, в - 14 діб, г - 21 доба; по осі абсцис - тканини (органи) молюсків, по осі ординат - вміст $\beta$-каротину (мг/г сирої тканини); $\mathrm{n}=10$ для кожного варіанта досліду

Аналіз тканинно-органного розподілу $\beta$-каротину в організмі L. stagnalis за обговорюваних умов дозволяє вибудувати такий метаболічний ряд тканин та органів у порядку зменшення в них вмісту досліджуваних сполук: мантія > гепатопанкреас $>$ нога $>$ гемолімфа. Отримані результати корелюють із даними інших дослідників (Gordzjalkovskij and Makurina, 2006, 2007), які вказували на підвищення вмісту каротиноїдних пігментів у зябрах, мантії, нозі та гепатопанкреасі Unio pictorum у відповідь на дію $\mathrm{ZnSO}_{4}$, $\mathrm{CuSO}_{4}, \mathrm{KMnO}_{4},\left(\mathrm{CH}_{3} \mathrm{COO}\right)_{2} \mathrm{Cd}$ та фенолу уже в концентрації, що відповідала ГДК (експозиція - 18 годин).

За умов збільшення концентрації токсиканта у водному середовищі (5-10 ГДК) зафіксоване зниження вмісту $\beta$-каротину у гемолімфі (на $52,8-43,3 \%$ ) та гепатопанкре- aci (на 11,9-44,7\%) молюсків. Одночасно з цим у мантії зареєстровано суттєве зростання значень досліджуваного каротиноїду (у 30,7 та 1,8 раза відповідно), однак у нозі не встановлено статистично достовірної різниці між показниками контрольної та дослідної груп за дії 5 ГДК токсиканта та зафіксоване зниження вмісту $\beta$-каротину на $16,7 \%$ за концентрації амоній хлориду 10 ГДК. При пролонгуванні інтоксикаційної дії $\mathrm{NH}_{4} \mathrm{Cl}$ (7 діб) посилюється його інгібувальний вплив на активність компонентів антиоксидантного захисту в організмі L. stagnalis, оскільки відомо, що зниження вмісту каротиноїдів у тканинах за впливу забруднення супроводжується депресією ключових ферментів антирадикального захисту СОД і КАТ і падінням ресурсу відновленого глутатіону (ГSH) 
(Soldatov et al., 2007). Незалежно від концентрації токсичного агента вміст $\beta$-каротину зменшується в усіх тканинах і органах L. stagnalis: на 45,7-92,6\% у гемолімфі, на 34,3$96,0 \%$ у гепатопанкреасі, на $31,7-84,7 \%$ у мантії та на 23,6-94,8\% у нозі досліджених тварин порівняно з показниками контрольної групи (Р < 0.01). При цьому найсуттєвіше зниження вмісту для всіх тканин (органів) зареєстроване за дії токсиканта, концентрацією, що відповідала 5 ГДК. Така закономірність має тимчасовий характер адаптації до дії амоній хлориду, що змінюється фазою виснаження внаслідок порушення адаптаційних механізмів цих тварин. Таке зниження зумовлене перетворенням деяких каротиноїдів в організмі молюсків на вітамін А, який є обов'язковим компонентом елементарних клітинних мембран (McCollum, 1967). Виняток із загальної тенденції становить мантія досліджених молюсків, у якій вміст $\beta$-каротину за максимального дозового навантаження (10 ГДК токсиканта) перебував у межах значень контрольної групи.

Подальше пролонгування експозиції молюсків у середовищі з $\mathrm{NH}_{4} \mathrm{Cl}$ до 14 діб (0,5 ГДК токсиканта) супроводжується збільшенням вмісту $\beta$-каротину в усьому організмі L. stagnalis: у 1,79 раза у гемолімфі, у 2,04 раза у гепатопанкреасі, у 1,68 раза у мантії та у 2,24 раза у нозі. Такий ефект зумовлений зміною каротиноїдами просторової конфігурації та переходом їх зі зв'язаної з ліпідами та білками (шляхом денатурації) у вільну форму. Іони амонію пошкоджують мітохондрії клітини та негативно впливають на процеси дихання в них (Toyomizu et al., 1999), а тому функцію енергозабезпечення клітин перебирають каротиноксисоми, які містять каротиноїди та систему термінального окиснення. Зі зростанням токсичності середовища від 2 до 10 ГДК зафіксовано зменшення обговорюваних показників на 33,2-69,2\% у гепатопанкреасі, мантії та нозі тварин (виняток становить мантія молюсків за дії 5 ГДК токсиканта). Що стосується гемолімфи тварин, то відмічено збільшення вмісту $\beta$ каротину (на 85,0\%) за дії 2 ГДК токсиканта та його зменшення (на 39,9-81,1\%) за токсичного впливу амоній хлориду, концентраціями 5-10 ГДК.

Така нелінійна динаміка вмісту $\beta$-каротину в організмі L. stagnalis пов'язана з метаболічними перетвореннями $\beta$-каротину на інші каротиноїди, які не фіксуються при обраній нами довжині хвилі, однак така тенденція була відмічена і для морських гідробіонтів (Soldatov et al., 2007). Збільшення часу контакту L. stagnalis iз $\mathrm{NH}_{4} \mathrm{Cl}$ (0,5 ГДК) до 21 доби спричинило різке зростання досліджуваних показників (у 3,89-7,38 раза) в усьому організмі L. stagnalis $(\mathrm{P}<0.01)$.

Як уже зазначалось, однією з фізіолого-біохімічних змін організму гідробіонтів за інтоксикації $\epsilon$ комплексні перебудови структури та функцій клітинних мембран, зміна їх проникності, функціонування транспортних систем та іонного гомеостазу (Kostjuk, 2011), а тому таке зростання показників можна пояснити участю обговорюваних пігментів у стабілізації мембран за токсичної діï, оскільки збільшення вмісту каротиноїдів співвідноситься з ущільненням і зменшенням плинності мембран (Vershinin, 1996), що свідчить про їх участь у формуванні бар'єрів, які перешкоджають проникненню токсиканта у клітину. Однак у міру збільшення концентрації полютанта $(2,5,10$ ГДК) зафіксоване по- силення токсичного ефекту амоній хлориду, що проявляється у зменшенні вмісту $\beta$-каротину у тканинах (органах) тварин: на 52,1-80,6\% за дії 2 ГДК, на 72,978,4\% за дії 5 ГДК та на 82,3-93,5\% за дії 10 ГДК токсиканта порівняно з контрольною групою тварин.

Отже, одночасне зростання концентрації токсиканта та часу перебування у забрудненому середовищі спричинює пригнічення процесів метаболізму молюсків та пошкодження структури молекул і мультимолекулярних комплексів. Останнє зумовлює незворотні функціональні зміни, які супроводжуються прогресуючим зниженням біохімічних та фізіологічних показників організму цих тварин.

Вміст ксантофілів в організмі L. stagnalis за токсичної дії амоній хлориду. Зміна вмісту ксантофілів за дії амоній хлориду є тканинно-специфічною, має дозозалежний характер та значно варіює залежно від тривалості експозиції молюсків у розчинах із досліджуваним токсикантом (рис. 2).

За короткострокового перебування молюсків (2 доби) у розчинах амоній хлориду концентрацією, що відповідала 0,5 ГДК, вміст обговорюваних пігментів збільшується у гепатопанкреасі (на 72,0\%), мантії (на 71,3\%) та нозі (на 88,6\%). Таке збільшення показників зумовлене антиоксидантними властивостями цих сполук, присутніх у біологічних мембранах у вигляді пігментнобілкових комплексів i здатних ефективно захищати мембрани та ліпіди клітин від руйнування вільними радикалами (Krinsky, 1994). Із загальної динаміки вибивається гемолімфа, для якої за даних умов зафіксоване зменшення вмісту ксантофілів на 36,5\% порівняно з показниками контрольної групи. Зазначимо, що гемолімфа не $є$ індикатором забруднення середовища, а слугує лише джерелом перенесення каротиноїдів (Prosser, 1977), у той час як депонування цих сполук відбувається у гепатопанкреасі. Наші результати узгоджуються 3 раніше отриманими експериментальними даними (Stadnichenko et al., 2002, 2007), які вказували на зниження вмісту каротиноїдів у гемолімфі L. stagnalis за дії сульфату міді та фенолу. Таку саму динаміку вмісту досліджуваних пігментів у гемолімфі за дії фенолу (501000 мг/дм ${ }^{3}$ ) відмічено і для L. fragilis, i, що цікаво, для Planorbarius corneus та P. purpura (Stadnichenko et al., 1985), які належать до фітофагів, на відміну від молюсків родини Lymnaeidae, які у переважній більшості є детритофагами (Kirichuk, 2002).

У разі зростання токсичного навантаження до 2 ГДК зафіксовано статистично достовірне збільшення вмісту ксантофілів у гемолімфі тварин (у 6,49 раза), оскільки гемолімфа $є$ головним детермінантом розповсюдження речовин до тканин і органів тварин. У випадку підвищення концентрації токсиканта до 5 та 10 ГДК відмічено зменшення вмісту ксантофілів на $11,7 \%$ та 52,3\% відповідно. Таке ж зниження (на 32,5-67,3\%) досліджуваних показників за дії вищих концентрацій $(2,5,10$ ГДК) зафіксоване і у гепатопанкреасі молюсків. Разом із цим, у мантії та нозі тварин концентрація амоній хлориду, що відповідає 2 ГДК, викликає зменшення вмісту ксантофілів, а за умов зростання концентрації (5 та 10 ГДК) - до його збільшення на 10,7-49,8\% відносно контролю.

Збільшення часу перебування молюсків у токсичних розчинах до 7 діб спричинило пригнічення їх метаболізму 
та викликало, незалежно від концентрації токсиканта, прямо пропорційне зниження вищезазначених показників (на 49,0-79,4\%) у їх гемолімфі. У гепатопанкреасі та мантії тварин також зареєстровано зменшення вмісту обговорюваних каротиноїдів за дії амоній хлориду концентрацією 0,5 та 2 ГДК (на 40,4-82,6\% та 47,8-54,5\%) та його збільшення в 1,13-3,29 раза зі зростанням токсичності середовища до такої, що відповідала 5 та 10 ГДК. Що стосується ноги L. stagnalis, то в даному органі $0,5,2$ та 5 ГДК токсиканта спричинювали зменшення вмісту ксантофілів (на 32,2-78,1\%), а найвища його концентрація (10 ГДК) зумовлювала незначне зростання показників (на 13,7\% відносно контролю). Отримані результати свідчать, що на 14-ту добу експозиції молюсків у водному середовищі з амоній хлоридом спостерігаються різнонапрямлені зміни вмісту сумарних ксантофілів в їх організмі. Ми встановили підвищення вмісту обговорюваних каротиноїдів у гемолімфі тварин за дії низьких концентрацій (на 45,2 та 15,4\%) та їх зниження за дії високих концентрацій (на 53,6\% та 46,2\% відносно контролю). У гепатопанкреасі, мантії та нозі L. stagnalis зростання показників викликала лише допорогова концентрація (0,5 ГДК) відповідно на $107,0 \%, 57,8 \%, 87,8 \%$, у той час як усі інші використані в експерименті концентрації проявили інгібувальну дію та зумовлювали статистично достовірне зниження вмісту ксантофілів у цих органах.
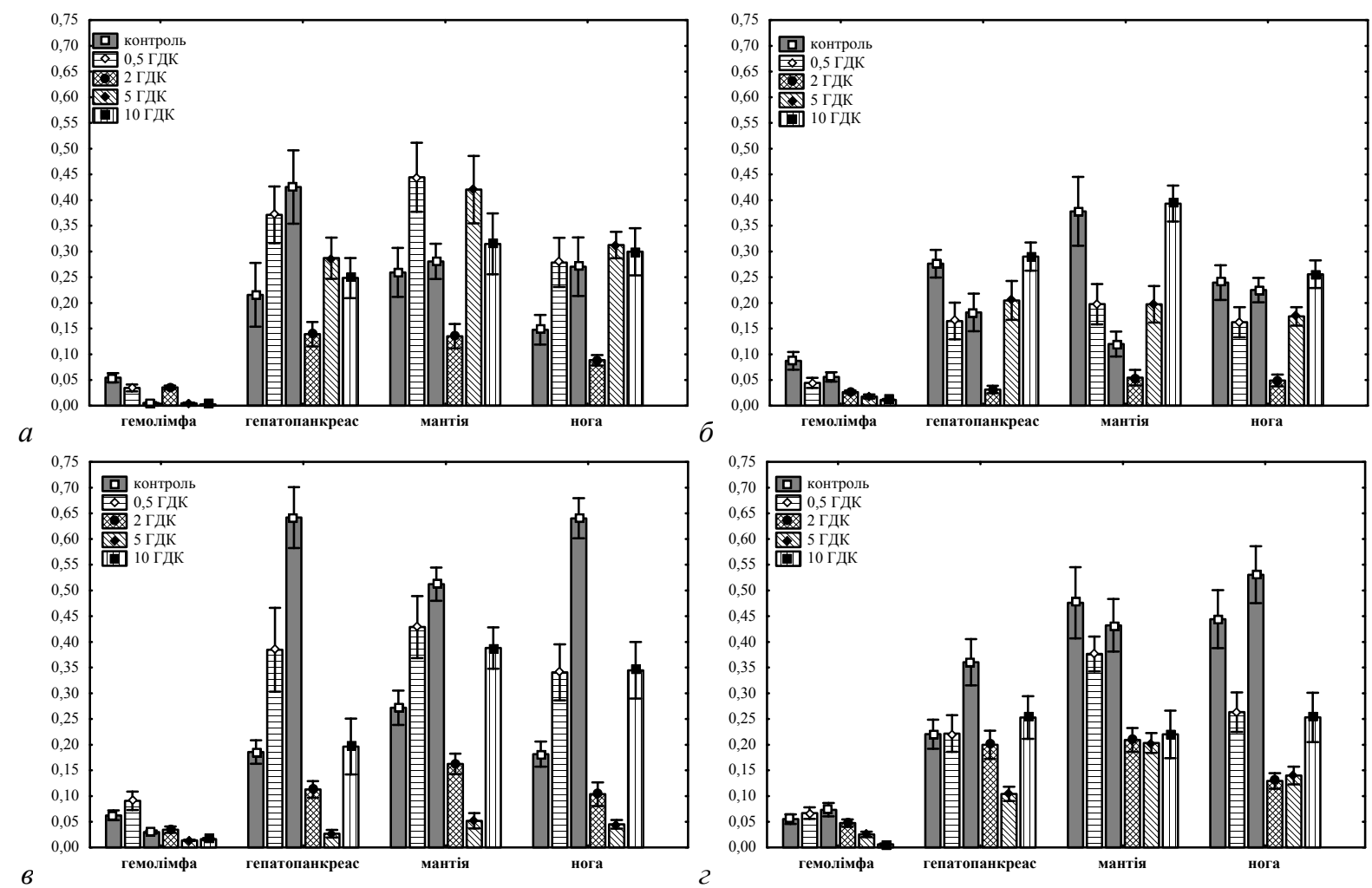

Рис. 2. Вплив амоній хлориду (0,5-10 ГДК) на вміст ксантофілів в організмі L. stagnalis: $a$ - експозиція 2 доби, $\sigma-7$ діб, в - 14 діб, г - 21 доба; по осі абсцис - тканини (органи) молюсків, по осі ординат - вміст ксантофілів (мг/г сирої тканини); $\mathrm{n}=10$ для кожного варіанта досліду

У міру збільшення часу (21 доба) перебування у водному середовищі амоній хлориду (0,5 ГДК) відмічено підвищення вмісту ксантофілів у гемолімфі досліджених гідробіонтів (на 21,0\%), однак у мантії та нозі зафіксовано його зменшення $(\mathrm{P}<0,01)$ на 20,9\% та 40,7\% відповідно. Що стосується гепатопанкреасу, то в даному органі не вдалося встановити статистично достовірних відмінностей між дослідною та контрольною групами тварин за значенням вмісту в ньому обговорюваних каротиноїдів. Інкубування L. stagnalis (21 доба) у розчинах $\mathrm{NH}_{4} \mathrm{Cl}$, концентраціями 2-10 ГДК викликало зниження показників у всьому їх організмі: на 35,2-91,6\% у гемолімфі, на $29,9-71,1 \%$ у гепатопанкреасі, на 49,1-52,9\% у мантії та на 52,3-75,6\% у нозі тварин, що зумовлено пошкодженням мембран (через посилення окиснювальних процесів), які є першим бар'єром на шляху зовнішніх стресорів, i, як наслідок, порушенням механізмів транспорту ксантофілів у клітини гідробіонтів.

\section{Висновки}

Зміни вмісту $\beta$-каротину та ксантофілів в організмі L. stagnalis мають адаптивний характер, що проявляється у певних межах токсичного навантаження, та направлені на підтримання гомеостазу гідробіонтів за дії амоній хлориду.

Дія обговорюваного токсиканта уже в низьких концентраціях (0,5 та 2 ГДК) за короткострокової експозиції (2 доби) викликає стимуляцію адаптивних процесів, що, як правило, має прояв у збільшенні вмісту як $\beta$-каротину, так і ксантофілів у всьому організмі L. stagnalis (виняток становить гемолімфа за дії 0,5 ГДК токсиканта).

Збільшення терміну експозиції до 7 діб незалежно від концентрації токсиканта викликає статистично достовірне 
зменшення вмісту $\beta$-каротину та ксантофілів у тканинах (гемолімфа) та органах (гепатопанкреас, мантія, нога) L. stagnalis.

У разі подовження часу інтоксикації амоній хлоридом до 14 діб зафіксовано збільшення вмісту як $\beta$-каротину, так і ксантофілів у гемолімфі, гепатопанкреасі, мантії та нозі тварин за дії найнижчої дози токсиканта (0,5 ГДК), який у міру збільшення токсичності середовища до 2, 5 та 10 ГДК знижується відносно контролю в усіх досліджених органах молюсків.

Збільшення часу контакту L. stagnalis iз $\mathrm{NH}_{4} \mathrm{Cl}$ до 21 доби зумовило статистично достовірне збільшення вмісту $\beta$-каротину (у 3,89-7,38 раза) в усьому організмі L. stagnalis за дії допорогової концентрації (0,5 ГДК) токсиканта та його зменшення $(\mathrm{P}<0,01)$ за умов збільшення токсичності водного середовища до 2, 5 та 10 ГДК.

Мінімальними значеннями вмісту $\beta$-каротину та ксантофілів характеризується гемолімфа тварин незалежно від концентрації токсиканту та тривалості його дії на організм. Максимальні показники мали дозозалежний характер та варіювали між органами (тканинами) залежно від тривалості експозиції тварин у токсичному розчині.

\section{Бібліографічні посилання}

Britton, G., 1986. Biohimija prirodnyh pigmentov [Biochemistry of natural pigments]. Mir, Moscow (in Russian).

Ercal, N., Gurer-Orhan, H., Aykin-Burns, N., 2001. Toxic metals and oxidative stress. Part I: Mechanisms involved in metalinduced oxidative damage. Curr. Top. Med. Chem. 1(6), 529-539.

Gautam, R.K., Parihar, R., 1996. Lead and mercury alters lipid contents in liver and kidney of Heteropneustes fossilis. Uttar. Pradesh. J. Zool. 16(1), 28-30.

Gordzjalkovskij, A.V., Makurina, O.N., 2006. Vodnye molljuskiperspektivnye obekty dlja biologicheskogo monitoringa [Water molluses as perspective objects for biological monitoring]. Vestnik SamGU. Estestvennonauchnaja serija 7(47), 37-44 (in Russian).

Gordzjalkovskij, A.V., Makurina, O.N., 2007. Vlijanie fenola na soderzhanie karotinoidov $\mathrm{v}$ tkanjah molljuskov [Effect of phenol on the content of carotinoides in the mollusc tissues]. Vestnik SamGU. Estestvennonauchnaja serija 8(58), 60-68 (in Russian).

Gostjuhina, O.L., Soldatov, A.A., Golovina, I.V., Borodina, A.V., 2012. Soderzhanie karotinoidov i sostojanie antioksidantnogo fermentativnogo kompleksa tkanej u dvustvorchatogo molljuska Anadara inaequivalvis [Content of carotenoids and the state of tissue antioxidant enzymatic complex in Bivalve mollusc Anadara inaequivalvis Br.]. Zhurnal Jevoljucionnoj Biohimii i Fiziologii 48(6), 542-547 (in Russian).

Grubinko, V.V., 2011. Rol' metaliv v adaptacii gidrobiontiv: Evoljucijno-ekologichni aspekty [A role of metals is in adaptation of aquatic organisms: Evolutional and ecological aspects]. Naukovi Zapysky Ternopilskogo Nacionalnogo Pedagogichnogo Universytetu Imeni Volodymyra Gnatjuka. Serija: Biologija 2(47), 237-262 (in Ukrainian).

Halliwell, B., Gutteridge, J.M.C., 1985. Free radicals in biology and medicine. Oxford Clarendon Press, Oxford, UK.

Hlebovich, V.V., 1981. Akklimacija zhivotnyh organizmov [Acclimation of animal organisms]. Nauka, Leningrad (in Russian).

Johnson, E.J., 2002. The role of carotenoids in human health. Nutr. Clin. Care. 5(2), 56-65.
Kirichuk, G.Y., 2002. Osobennosti nakoplenija ionov tjazhelyh metallov presnovodnymi molljuskami [Peculiarities of cumulation of heavy-metal ions by freshwater mollusks]. Visn. Zhytomyr. Derzh. Ped. Univ. im. I. Franka 10, 170-175 (in Russian).

Kostjuk, K.V., 2011. Strukturno-funkcionalni reakcii klityn vodnyh roslyn na diju toksykantiv [Structural and functional response of water plant cells to theaction of toxicants]. Kyiv (in Ukrainian).

Krinsky, N.I., 1994. The biological properties of carotenoids. Pure Appl. Chem. 66(5), 1003-1010.

Lappivaara, J., 2001. Effects of acute handling stress on whitefish Coregonus lavaretus after prolonged exposure to biologically treated and untreated bleached kraft mill effluent. Arch. Environ. Contam. Toxicol. 41(1), 55-64.

Leus, J.V., 1998. Perekysne okysnennja lipidiv ta antyoksydantnyj zahyst u ryb pid vplyvom faktoriv vodnogo seredovyshha [Lipid peroxidation and antioxidant protection in fish exposed aquatic environment factors]. Kyiv (in Ukrainian).

McCollum, E.V., 1967. The paths to the discovery of vitamins A and D. J. Nutr. 91(2), 32-38.

Metelev, V.V., Kanaev, A.I., Dzasohova, N.G., 1971. Vodnaja toksikologija [Aquatic toxicology]. Kolos, Moscow (in Russian).

Parke, D.V., 1987. Activation mechanisms to chemical toxicity. Arch. Toxicol. 60(1-3), 5-15.

Potrohov, A.S., 2008. Snizhenie antistressovymi preparatami nervnoparaliticheskogo dejstvija vysokoj koncentracii ammonija na ryb [Reduction of neuroparalytic action of ammonium in high concentrations on fish by antistressing preparations]. Dopovidi NANU 9, 156-162 (in Russian).

Simahina, G.O., 2010. Funkcionalna rol karotynoidiv ta osoblyvosti ih vykorystannja u harchovyh tehnologijah [The functional role of carotenoids and peculiarities of their use in food technology]. Proceedings NUFT 33, 45-48 (in Ukrainian).

Soldatov, A.A., Gostjuhina, O.L., Golovina, I.V., 2007. Antioksidantnyj fermentnyj kompleks tkanej dvustvorchatogo molljuska Mytilus galloprovincialis Lam. v norme i uslovijah okislitelnogo stressa (obzor) [Antioxidant enzyme complex of tissues of the bivalve Mytilus galloprovincialis Lam. under normal and oxidative-stress conditions: A review]. Prikladnaja Biohimija i Mikrobiologija 43(5), 621628 (in Russian).

Stadnichenko, A.P., 1970. Izmenenija belkovogo spektra krovi Viviparus contectus (Millet, 1813) (Gastropoda, Prosobranchia) pri invazii lichinochnymi formami trematod [On variations in the blood albuminous spectrum of Viviparus contectus (Millet, 1813) (Gastropoda, Prosobranchia) caused by invasion with larval forms of trematodes]. Parazitologija (Parasitology) 5, 484-488 (in Russian).

Stadnichenko, A.P., Ivanenko, L.D., Mostipaka, O.A., Stepchuk, L.O., Gomenjuk, R.A., 2002. Vlijanie sulfata medi na soderzhanie karotinoidov $\mathrm{v}$ gemolimfe prudovika ozernogo (Mollusca: Pulmonata: Lymnaeidae) v norme i pri invazii ego partenitami trematod [Trematoda invasion and sulphate copper impact upon carotenoids of haemolymph of Lymnaea stagnalis (Mollusca: Pulmonata: Lymnaeidae)]. Visn. Zhytomyr. Derzh. Ped. Univ. im. I. Franka 10, 197-201 (in Russian).

Stadnichenko, A.P., Misechko, L.E., Shepel, A.N., 1985. Vlijanie fenolnoj intoksikacii na soderzhanie karotinoidnyh pigmentov $\mathrm{v}$ gemolimfe presnovodnyh molljuskov (Pulmonata, Lymnaeidae i Bulinidae) v norme i pri zarazhenii partenitami trematod [The effect of phenol intoxication on the carotinoid pigments contents in haemolymph of freshwater molluscs (Pulmonata, Lymnaeidae, Bulinidae) in normal conditions and during their infection with parthenites of trematodes]. Parazitologija 19(2), 101-104 (in Russian).

Stadnychenko, A.P., Astahova, L.J., Gyryn, V.K., 2007. Vplyv fenolnoi intoksykacii na vmist karotynoidiv u gemolimfi prisnovodnyh moljuskiv u normi i za invazii ih trematodamy 
[The effect of phenol intoxication on the carotenoid content in haemolymph of freshwater molluses in normal conditions and during their of trematode infection]. Materials of the third international scientific conference «Development of scientific research», 65-67 (in Ukrainian).

Tilak, K.S., Lakshmi, S.J., Susan, T.A., 2002. The toxicity of ammonia, nitrite and nitrate to the fish, Catla catla (Hamilton). J. Environ. Biol. 23(2), 147-149.
Toyomizu, M., Yamahira, S., Tanaka, M., Akiba, Y., 1999. Effects of ammonium chloride-induced acidosis on oxidative metabolism in liver mitochondria of chicks. Brit. Poultry Sci. $40,541-544$.

Vershinin, A., 1996. Carotenoids in mollusca: Approaching the functions. Comp. Biochem. Physiol. 113(1), 63-71.

Надійшла до редколегії 17.09.2015 